\title{
ESP in a Saudi Context: Where Does It Stand?
}

\author{
Muhammad Al-Roomy \\ King Saud bin Abdulaziz University for Health Sciences, Riyadh, Saudi Arabia
}

\begin{abstract}
English for specific purposes (ESP) gains more status in Saudi Arabia due to the continuing and sustainable growth in the development of various fields for academic and professional purposes. Using English as a means of communication in teaching and learning is one of them. The aim of this study is to critically review the previous research carried out in a Saudi context in the area of teaching and practicing English at specific schools, universities, and colleges for specific or special purposes (ESP) in the last ten years, in order to identify the current developments and to suggest new research directions. The investigation of the research body is based on an examination of the researched topics, with reference to the three research components, i.e., research approaches, research designs, and research methods (Creswell 2014). The results revealed that many research topics were examined, such as students' attitudes and motivation to learn, needs analysis, program or course development, and the evaluation and teaching of language skills. However, it was unclear how researchers, who were all ESP teachers, related their findings to the ESP context in terms of students' specific needs. It also showed that the majority of studies carried out were quantitative in nature, and thus, led themselves to utilizing mainly a questionnaire as a research tool. The study concluded with some recommendations and pedagogical implications, which hopefully, will reverberate with other studies for further research.
\end{abstract}

Index Terms - ESP, higher education, research development, new research directions

\section{INTRODUCTION}

Many researchers have examined the area of ESP (English for specific or special purposes) and its relevance to teaching and learning (Hutchinson and Waters, 1987, and Dudley-Evans and St. John, 1998). ESP is considered a subfield of language for specific purposes (LSP), in which learners need to use the target language, i.e., English, as a medium of communication to fulfill specific needs, rather than learning it for its own sake (Richards and Rodgers, 2003). ESP can take different forms, depending on learners' needs, such as the degree of specificity or experience that is appropriate for the course (Robinson, 1991). Nevertheless, the focal point of any categorisation of ESP is that English is not taught as a separate subject, but is constructed around functions determined by the purposes of the learners. Hutchinson and Waters (1987, p.19) state that, directly, "ESP should probably be seen not as any particular language product, but as an approach to language teaching, which is directed by specific and apparent reasons for learning." It is clear that the focus is on the process of language learning not on the actual use of language.

Students who are involved in the ESP context need to be proficient users of English with the highest possible caliber in order to pursue their studies and have access to different recourses in scientific fields such as medicine, engineering, computing, and physics. The reason for giving English a dominant role students need most is caused by its global status around the world. English holds a privileged status globally for many reasons, whether it is regarded as a first or second language, or a lingua franc with official status in many countries. Crystal (2003, p.7) explains what makes English a global language by noticing

There is the closest of links between language dominance and economical, technological, and cultural power, too, and this relationship will become increasingly clear as the history of English is told.

Jenkins (2007, p.2) defines English as a lingua franca (EFL) as the use of English as a common language among people who have different mother tongues, and he refers to it by stating that "it is a foreign language of communication." Crystal (2003, p.22) advocates that there is "a need for mutual intelligibility and identity" in order to make EFL users successful.

Similarly, Nunan (1999) takes a step further and holds that viewing English as a global language necessitates the need to change the policies and practices of teaching and learning English.

ESP researchers have focused on practical aspects, such as course design and material design (Dudley-Evans and St. John, 1998) or case descriptions of research projects related to individual teaching. As a result, the approaches and ideas underlying certain practices and individual cases are not well identified in order to make a link between theory and practice (Basturkmen, 2006). Patridge and Starfield (2011) assert that considering English as a lingua franca, i.e., the language of worldwide communication, whereby nonnative speakers of English use English for their own purposes, leads researchers in the field of ESP to consider new directions for its pedagogical implications. Nickerson (2005), when discussing the issue of English as a lingua franca and research on business English, provides two trends related to such investigation. First, research shifts the focus of tackling in isolation the examination of language of spoken or written texts toward the analysis of the communicative contexts and how the organizational and cultural factors affect the written and spoken texts. Second, it is suggested that EAP and ESP are both needs driven, i.e., students have 
different needs and purposes in their minds to study English, which influence their motivation for learning (Nickerson, 2005).

So far, there has been little critical discussion of the place of ESP researches in a Saudi context. While a considerable amount of research has, so far, been conducted in teaching English for academic purposes in the Saudi context, a rather small number of studies have been conducted for ESP purposes.

This is not surprising, because most of the English language courses are directed to general purposes to enable students to communicate in English effectively for daily life. Therefore, such investigation is intended to determine whether or not the issue of ESP has been addressed thoroughly to advance our understanding of its nature and delineate its characteristics, and to offer theoretical support for both ESP teachers and researchers. To this effect, the following research questions have been formulated.

1- What ESP areas have been explored by researchers?

2- What research approaches and methods have been utilized by previous research?

3- To what extent do the current studies provide a theoretical and practical foundation for further research?

\section{LITERATURE REVIEW}

\section{A. English for General and Specific Purposes}

English language teaching (ELT) has two branches, i.e., English for specific or special purposes (ESP) and English for general purposes (EGP) (Hutchinson and Waters, 1987). On the other hand, English for academic purposes (EAP) is considered a division of ESP (Dudley-Evans and St. John, 1998). Regarding EAP as a division of ESP leads to another classification, proposed by Jordan (2003), who compares English for general academic purposes (EGAP) with English for specific academic purposes (ESAP). Hutchinson and Waters (1987) highlight three factors related to the emergence of ESP: the dominant role of English to serve particular needs in technology and commerce, new developments in linguistics and what to teach students, and addressing ESP as a learner-centered approach. The origins of English for specific purposes (ESP) can be traced back to the 1960s, when the focus was on learners' needs of study (Dudley-Evans and St. John, 1998). The different divisions and categorizations of ESP and EGP suggest that there are some similarities and differences between the two sets. Hutchinson and Waters (1987: 53), when discussing the difference between ESP and EGP, comment that it is "in theory nothing, in practice a great deal." One way to look at the similarities and differences between English for general and specific purposes is to examine the characteristics of each type. Due to the unique nature of ESP, certain characteristics are proposed by researchers (e.g., Strevens, 1988, and Dudley-Evans and St. John, 1998). Dudley-Evans and St. John (1998, pp. 4-5) identify the following characteristics to account for the differences and similarities between ESP and general English.

I. Absolute Characteristics

- ESP is defined to meet the specific needs of the learner;

- ESP makes use of the underlying methodology and activities of the discipline it serves; and

- ESP is centered on the language (grammar, lexis, register), skills, discourse, and the genres appropriate to these activities.

II. Variable Characteristics

- ESP may be related to or designed for specific disciplines;

- ESP may use, in specific teaching situations, a different methodology from that of general English;

- ESP is likely to be designed for adult learners, either at a tertiary level institution or in a professional work situation. It could, however, be designed for learners at the secondary school level;

- ESP is generally designed for intermediate or advanced students; and

- Most ESP courses assume some basic knowledge of the language system, but it can be used with beginners.

Prior to Dudley-Evans and St. John's classification, Strevens (1988) proposed another classification, which includes the absolute characteristics that "ESP is in contrast with general English," and he limited the variable characteristics to include only two, in comparison to Dudley-Evans and St. John's classification, which included more.

\section{B. ESP in Saudi Arabia}

In light of the continuing and sustainable growth in development, Saudi Arabia has witnessed a boom in various fields of health affairs, technology, science, and economy, due to the government's plans to promote human development in recent years (Rahman and Alhaison, 2013, AL-Seghayer, 2014). For the educational sector, the government allocates a generous, high percentage of the state budget for building new schools, establishing new universities, developing curricula, and improving teaching practices, which takes into account the needs of learner and society and the configuration of the labour market. For its inevitable importance, English is an integral component of the Saudi education system. As part of curricula development, English received special attention and has undergone different stages of development, including reshaping the desired goals and objectives, contents, methods of teaching, and learning environment. Among many initiatives and projects in 2014, the Saudi Ministry of Education has implemented a project called the English Language Development Project (ELDP), which is considered part of a large reform project for developing the educational system under the King Abdullah Project for General Education Development for the development of public education (Tatweer, 2014). 
Due to the English language dominant position, ESP courses are taught for various reasons to obtain different degrees (Ahmed, 2012). For example, some institutes offer high school degrees, such as the Industrial and Advanced Construction secondary institutes run by the Technical and Vocational Training Cooperation, or diplomas, such as Technical Colleges and Information and Telecommunication colleges. The majority of universities provide bachelor degrees in different majors, like medicine, engineering, technology, business, and computing. Fewer programs are intended for students to complete their postgraduate master or PhD studies in different ESP majors. Some military colleges offer some ESP courses to students as a requirement to finish certain programs, such as English to teach logistics or aviation. In the preparatory year, all students who want to pursue their studies in majors like medicine, business, and engineering have to take general and specific English courses before they begin full-degree programs.

\section{Different Types of Research}

As a complex and systematic process, various types of research have been adopted, each of which is guided by a particular interest. For example, Kumar (2010) divides research into three different types, from the point view of 1) application of the findings, e.g., pure and applied research; 2) objectives of the study, e.g., descriptive and explanatory researches; and 3) mode of inquiry, e.g., qualitative and quantitative research. Kumar adds that such a classification is not exclusively limited; some types of research may share the classification of others.

There is a strong relationship between second-language research and teaching in a second language or foreign context. Pica (1997) holds that the teaching-research relationship can be seen in relation to coexistence, collaboration, complement, and compatibility. She adds that the focus of L2 research has shifted to tackle issues such as teaching practices informed by different teaching methodologies, instructional materials, and classroom practice. Mackey and Gass (2016) observe that second-language research enables both researchers and teachers to obtain a better understanding of the nature of teaching and learning, as well as factors affecting each aspect. However, it should be noted that not all second-language learning research might be applicable to classrooms because of the "changing dynamics of the learning context" (Mitchell and Myles, 2004, p. 261).

Some kinds of research are preferable for examining some topic areas, such as reading comprehension, especially if they are not well supported by research. One example is an action research, which is a form of teacher research process in which teachers research their own practice systematically and critically to bring about change (Grabe and Stoller, 2002). The selection of a certain approach depends on the nature of the research under study with reference to its purpose and how much data are needed (Denscombe, 2014). Creswell (2014) asserts that research problems, personal experiences, and audience are all factors affecting the choice of a certain approach. However, the choice of any approach does not mean the rigid adherence to that approach (Bell and Waters, 2014). From a broader perspective, all research can be divided into three main types: qualitative, quantitative, and mixed research. Bryman (2008) highlights that, in a simple way, quantitative research is concerned with quantification, while qualitative research emphasises words for data collection and analysis. However, this distinction is not enough to account for the differences between the two strategies. There are some fundamental differences between the two strategies in terms of the role of theory in relation research, epistemological and ontological stances the research takes while conducing his or her study (Bryman, 2015). According to Creswell (2014), the distinction between qualitative and quantitative research is made by using specific jargon, like (qualitative) instead of using numbers to refer to (quantitative), using close-ended questions with quantitative research in comparison to open-ended questions implemented with qualitative design, or by looking at specific assumptions associated with each designs such methods and strategies of collecting and analysing data.

A third paradigm is called the mixed-research method, which was a reaction to a long debate between qualitative and quantitative researchers about many epistemological, ontological, and methodological assumptions. This approach allows researchers to share some elements of the two research methods, i.e., quantitative and qualitative, to tackle the research problem by implementing multiple methods for the collection and analysis of data (Teddile and Tashakkori, 2009). Denscombe (2014) holds that using a mixed-methods approach can enhance researchers' confidence in the accuracy of their findings, if they reach the same conclusion when triangulating two different research methods.

\section{Research Data Collection and Analysis}

Data that researchers have to deal with when gathering their information fall into two main sources: primary data and secondary data. Primary data are original in nature and collected by the researchers themselves. Such data are geared directly to the research problems, through interviews, questionnaires, and observations. Secondary data, in contrast, are in the shape of a finished product; they have already been collected by someone else, so they may not be totally relevant to the purpose of the researched study, such as documents and studies used in the literature review (Galvan, 2013). Both primary and secondary data analyses have advantages and disadvantages, but secondary data offer more benefits for researchers in comparison to primary data, as the latter are time-consuming and require more money and effort to conduct (Bryman, 2008). Up to this point, each research approach has various methods for data collection. Denscombe (2014) suggests the following considerations before selecting any method: 1) research methods are often linked to specific research designs; 2) each method has its advantages and disadvantages, and the role of the researcher is to determine what best suits the research problems; and 3) research methods should not be used in isolation, but should be combined to strengthen what has been found. For ESP research, Gollin-Kies (2014), has examined published articles between 2003 and 2012 in the ESP field to find out that there is a preference for publishing qualitative researches 
contradicting previous studies that suggest a trend to publish quantitative studies in the fields of applied linguistics and ESOL (English for speakers of other languages). The triangulation process is recommended in ESP research; this process combines the two approaches, thereby enriching the collected data (Long, 2005, Gollin-Kies, 2014).

\section{RESEARCH METHODOLOGY}

For the sake of the study, data were collected by examining 18 studies carried out in a Saudi context in the area of teaching and practicing English at specific schools, universities, and colleges for specific or special purposes (ESP) in the last ten years. Then the researches were critically analyzed. The examination of the researches' components was based on three components, i.e., research approaches, research designs, and research methods (Creswell 2014).

\section{RESULTS AND DisCUSSIONS}

The following account provides a critical review to answer the first and second research questions, which consider the topics discussed in different studies and approaches of research and techniques of data collection. Researchers worked on different research areas, which focused on the individual aspects of learners (Ellis, 1997). These areas are as follows:

First, some studies considered affective factors associated with language learners. For example, Javid et al. (2012) examined Saudi undergraduates' motivational orientations by distributing a questionnaire to identify whether any statistically significant differences existed due to the participants' gender and university major. The study concluded that female students majoring in medicine and technology information reported more positive motivational orientations, intrinsically and extrinsically, in contrast to their male counterparts; in addition, male participants majoring in English were more intrinsically and extrinsically motivated than female cohorts. In a similar study, Alhuqbani (2014) used a questionnaire to compare the motivation and attitudes of police cadets with their English language needs. The findings revealed that students' needs were centered around studying English for security purposes, and students were found to be instrumently and interpretively motivated, as long as they succeeded in meeting their needs.

Second, other studies looked at the role of needs analysis to facilitate language learning. Liton (2015) conducted a study to determine the real needs of learners of a business school and what they need after they graduate in the workplace by investigating an ESP course but from the teachers' perspective. For data collection, a questionnaire was administered to the ESP teachers, and the observations were triangulated. The findings showed that the ESP course design did not meet the specific needs of students in the work place, suggesting the need to replace the traditional teaching techniques with more communicative ones. In another study, Javid and Umer (2013) investigated the needs of undergraduate medical students in order to evaluate the appropriateness of ESP teaching materials. A questionnaire was distributed to students, and students' responses confirmed that ready-made materials cannot meet students' specific academic needs. Habbash and Albakawi (2014) conducted a needs analysis of engineering students' English needs, using a questionnaire addressed to both students and teachers. The results pointed out that being aware of students' interests and needs resulted in building self-confidence and positive attitudes toward English.

Third, another researched area was program development and evaluation. Alahmadi (2010) developed an interactive multimedia program for computing students, in order to introduce the basic technical English vocabulary they needed in their studies. Similarly, Alfehaid (2011) carried out a study to develop ESP courses at health sciences colleges. His study was based on a needs analysis and course program evaluation. He used a mixed-methods approach, including a questionnaire given to students, teachers, and graduates, as well as a semistructured interview carried out with students, graduates, teachers, course administrators, hospital managers, and health professionals. The program evaluation indicated that the ESP course was partially beneficial to students in their academic studies and for their target career. However, some practical issues related to learning-teaching materials and assessment procedures needed to be addressed. Fadel and Elyas (2015) carried out a study to introduce a scientific reading program and inject it with teaching English for general purposes. They used a questionnaire administered to students to uncover students' attitudes toward ESP. Results showed that students were willing to study ESP and that ESP programs should consider learners' needs to be a top priority for motivating students, rather than piquing their interest. Results also showed that ESP courses not only benefited students in their academic studies, but also improved their overall language proficiency. Younes (2016) carried out a study to examine the efficiency of ESP courses in the preparatory year, but from teachers' perspectives. By using a questionnaire, teachers reported that ESP courses were suitable for students in their academic study and for the workplace. However, the results suggested that the background and culture factors should be taken into account when designing such courses to address students' needs. Mahib ur Rahman (2012) carried out a study to evaluate the English writing text in order to determine how the writing text met students' requisite skills and learning needs. He used a questionnaire for the sake of data collection, and teachers reported that the prescribed book has some significant areas of strengths as well as some shortcomings.

Fourth, another researched area that researchers addressed pertained to the four language skills, i.e., listening, speaking, reading, and writing, and the subskills, i.e., grammar and vocabulary recognition. Alnufaie and Grenfell (2012) investigated the writing skills of an industrial college, implementing a questionnaire to determine how often students deployed product-oriented strategies in comparison to process-oriented strategies. The responses indicated that students 
diversified the two sets of writing strategies. Alamin and Ahmed (2012) investigated the writing of students to diagnose the syntactic and punctuation errors committed by science students during their first year of study while taking a technical writing course. They collected data from the quizzes, homework, and final examinations of students. Results showed that students lacked basic English grammar, which could be ascribed to intralingual interference.

Fifth, the final area of research has to do with the study and soft skills students adopt while learning. El-Gilany and El Sayed Abusaad (2013) examined the relationship between self-directed learning readiness and learning styles among Saudi undergraduate nursing students. Using a questionnaire, they determined that there was no association between self-directed learning readiness and demographics and learning styles. Mousawa and Elyas (2015) conducted a study to illuminate the importance of providing students with soft skills and, more specifically, communication skills and presentation. They argue that soft skills are as important as hard skills and they have direct relevance to academics and success in employability. Similarly, Al rebish and Taha (2017) integrated teaching communication skills into a health profession education course in order to improve the study skills of students who were enrolled in a preparatory year. Quantitative through a questionnaire and qualitative through focused group discussions. AL-Roomy (2017) investigated the efficiency of combining study skills with an academic study of English for medical students in a parallel program. He used semi structured interviews with students and teachers, as well as an open-ended questionnaire with students for the purpose of data collection. The results indicated that teaching study skills explicitly boosted students' English performance with their academic courses. In another study, Naser (2015) conducted a study to identify the vocabulary recognition strategies of science students via semi structured interviews, class observations, and two questionnaires. The study showed that teachers should be well prepared before teaching ESP courses, students had to be motivated and elevate their English proficiency, and prescribed books taken prior to university study should introduce scientific topics. Alzahrani and Alzahrani (2012) identified another effective element of learning, related to medical students' perceptions of their learning strategies, including learning habits, learning resources, and preferred teaching methods. They utilized a questionnaire submitted to students and found that students preferred self-instruction and practical sessions over lecturing.

Regarding the third research question of the current place of ESP in the Saudi context and its research directions in English, the following considerations summarize the place of ESP research in the Saudi context in terms of topics, methodology, methods, and suggestions for future research directions.

With respect to the research topics, researchers explored many areas, including needs analysis, program development and evaluation, and specific problems related to the process of teaching and learning, similar to other ESP areas of study previously investigated (Dudley-Evans and St. John, 1998, and Basturkmen, 2006). However, when examining the role of affective factors associated with the psychology of learning, some important factors were overlooked, such as ESP and the identity of learners, which are essential to maximize students' learning. The notion of social identity was first coined by Peirce (1995) to explain the relationship between language learners and the social world, and it suggested that such a relationship could be best understood via the power relations found in the interaction between language learners and the target language speakers. She argued that what guarantees successful learning is the learners' ability to construct and assert their own identity and have the full right to engage and reflect critically with native speakers and to be the subject of change with their identities, rather than being the subject to change with an identity they do not won (Peirce, 1985). Belcher and Lukkarila (2011) point out the important role that teachers have to enable ESP learners to determine their imagined identities in order to achieve their long-term learning goals, rather than the short-term ones. Learners should be the center of learning, and they should state what they want to learn and for what purposes through language (Belcher and Lukkarila, 2011). While researchers tried to explain how students meet their needs and communicate in English in their academic study, it was not clearly sought how they met these needs across professional boundaries. For example, no single study examined the students' need to communicate in English after having finished their education.

In relation to methods of collecting data, it is noticeable that the number of studies that implemented only one method, mainly the questionnaire, is larger than that of the studies that varied the data collection methods. Although the questionnaire is considered to be a useful tool for collecting data, easily and unanimously, from a large number of participants, all of the questions are fixed and prepared beforehand; thus, the researcher might think that all of the students came up with the same interpretations, which is not always true (Bryman, 2008). Such findings do not agree with other findings, which suggest that quantitative research methods were the most commonly used tools for collecting data among researchers (Gollin-Kies, 2014) and with those trends to implement more than one method to triangulate data (Long, 2005, Gollin-Kies, 2014).

Another issue is the role for ESP practitioners. Several researchers (Nunan, 1999, and Dudley Evans and St. John, 1998) proposed that ESP practitioners have to play different roles, such as teachers, course designers, researchers, and evaluators. However, some of these roles were not clearly covered in the above review, especially the role of ESP practitioners as researchers who strived to understand and improve their own practices in continuous professional inquiry. Action research, whereby teachers try to understand their own teaching practices, investigate, and reflect to bring about change in the classrooms, is considered to be an effective way of investigating. By conducing action research, teachers become participants, rather than recipients by playing the role of teacher-researcher (Porocka and Sierocha, 2013). 


\section{CONCLUSIONS AND RECOMMENDATIONS}

This study investigated the previous literature undertaken in a Saudi context with respect to developments in ESP research. The findings drawn from the research yielded some important results that may lend insight into the current value of ESP in a Saudi context and identify the areas of challenge and potential in order to offer theoretical support for further research. The main findings of this study are as follows.

First, varied research topics were examined, including the psychology of learning and learners, the role of needs analysis, program development, and the evaluation and teaching of language skills. However, little evidence was provided to support how researchers acted accordingly. For example, it was unclear how teachers could develop their own materials and vary their teaching methods to suit students' specific needs. If data suggest that students need to learn grammar and some technical vocabulary, teachers must consider that they should not teach the language as they intended when teaching EGL, but rather, they should focus on teaching about the language (i.e., cantering on the language) (Dudley Evans and St. John, 1998). In this case, researchers do need to find their own ways to link theory with practice, using their collected data (Basturkmen, 2006).

Another important point is that, when researchers examine the spoken or written language, the desired goal should be directed toward communicative competence, in which all classroom activities use meaningful and authentic communications, bearing in mind cultural and organizational factors (Nickerson, 2005).

Second, much of the research was based on quantitative techniques for collecting data and, more specifically, questionnaire tools, which might be attributed to the ease of using and analysing such a tool. Additionally, students' and teachers' perspectives were the main sources for collecting data, with few exceptions; further research should consider the views of policymakers, stakeholders, and course designers, in order to create a clearer picture of different aspects of ESP.

Third, the results revealed that it was unclear from the given studies if the ESP teachers really had degrees majoring in some fields, such as engineering, computing, and medicine, or if they just evinced interest in ESP courses. If teachers have an EGP background, they are more likely to resort to the same method of teaching ESP as they do EGP. For this reason, it is recommended that key issues of ESP be included in preservice teachers' programs and that training workshops be given for teachers to introduce them to the ESP realm and to discuss the prevailing issues they encounter while teaching. Finally, it is hoped that this study will reverberate with other studies to benefit the Saudi ESP context and relate it to the ELT world.

\section{REFERENCES}

[1] Alahmadi, B. (2010). ESP ICT Vocabulary for First-Term Students at Madinah College of Technology (MCT), Paper presented at the Proceedings of the $8^{\text {th }}$ international conference on Education and Information Systems, Technologies and Applications: EISTA, in the context of the $4^{\text {th }}$ the international multi-conference society, cybernetics and informatics: IMSCI, Orlando, Florida, USA, June $29^{\text {th }}-$ July $2^{\text {nd }}$ (pp.19-23).

[2] Ahmed, J. (2012). Theoretical Framework \& Growing Demand of ESP in Saudi Arabia, Archives Des Sciences, 65(5), 114-120.

[3] Alamin, A. \& Ahmed, S. (2012). Syntactical and Punctuation Errors: An Analysis of Technical Writing of University Students Science College, Taif University, KSA, English Language Teaching, 5(5), 2-8.

[4] Alhuqbani, M. (2014). An investigation of the English Language Needs, Motivations, and Attitudes of Saudi Police Cadets, International Journal of Applied Linguistics \& English Literature, 3(2), 201-213.

[5] Alfehaid, A. (2011). Developing An ESP Curriculum for Students of Health Sciences Through Needs Analysis and Course Evaluation in Saudi Arabia, (Unpublished PhD dissertation), University of Leicester.

[6] Alnufaie, M. \& Grenfell, M. (2012). EFL Students' Writing Strategies in Saudi Arabian ESP Writing Classes: Perspectives on Learning Strategies in Self-access Language Learning, SiSAL Journal, (4), 407-422.

[7] Alrebish, S. \& Taha, M. (2017). Evaluation of Communication Skills and Health Profession Education Course in the Preparatory Year at Qassim University, Kingdom of Saudi Arabia. Paper presented at the Proceedings of the Second National Conference for Prep Year in Saudi Universities, AL-Imam Muhammad Ibn Saud University, Riyadh, 8-9 March (PP.565-604).

[8] Al-Roomy, M. (2017). Tensions between Reasons for Teaching English and Objectives of the Preparatory Year Programme in a Saudi Medical University, Paper presented at the Proceedings of the Second National Conference for Prep Year in Saudi Universities, AL-Imam Muhammad Ibn Saud University, Riyadh, 8-9 March (PP.433-459).

[9] Al-Seghayer, K. (2014). The Four Most Common Constraints Affecting English Teaching in Saudi Arabia, International Journal of English Linguistics, 4(5)17-26.

[10] Alzahrani, H. \& Alzahrani, O. (2012). Learning strategies of medical students in the surgery department, Jeddah, Saudi Arabia, Advances in Medical Education and Practice, 3, 79-87.

[11] Basturkmen, H. (2006). Ideas and Options in English for Specific Purposes, Lawrence Erlbaum Associates, Inc.

[12] Belcher, D. \& Lukkarila, L. (2011). Identity in the ESP context: Putting the learner front and center in needs analysis. In D. Belcher, A. M. Johns, \& B. Paltridge (Eds.), New directions in English for specific purposes research (pp. 73-93). Ann Arbor, MI: University of Michigan Press.

[13] Bell, J. \& Waters, S. (2014). Doing Your Research Project: A Guide to first time researchers, 6th ed., Berkshire: Open University Press.

[14] Bryman, A. (2008). Social Research Methods, $3^{\text {rd }}$ ed. Oxford: Oxford University Press.

[15] Bryman, A. (2015). Social Research Methods, $5^{\text {th }}$ ed. Oxford: Oxford University Press.

[16] Creswell, J. (2014). Research Design, Qualitative,. Quantitative. and Mixed Methods. Approaches, $4^{\text {th }}$ ed. Thousand Oaks California: Sage Publication. 
[17] Crystal, D. (2003). English as a Global Language. Cambridge: Cambridge University Press. $2^{\text {nd }}$ ed.

[18] Denscombe, M (2014) The Good Research Guide: For Small-Scale Social Research Projects, $5^{\text {th }}$ ed. Berkshire: Open University Press.

[19] Dudley-Evans, T. \& St. John, M. (1998). Developments in English for Specific Purposes. a Multi-Disciplinary Approach, Cambridge: Cambridge University Press.

[20] El-Gilany, A. \& El Sayed, F. (2013). Self-directed learning readiness and learning styles among Saudi undergraduate nursing students, Nurse Education Today, 33, 1040-1044

[21] Ellis, R. (1997). Second Language Acquisition. Oxford : Oxford University Press.

[22] Fadel, S. \& Elyas, T. (2015). ESP Needs Analysis to Integrate a Scientific Reading Program in the English Language Institute at King AbdulAziz University, International Journal of Educational Investigations, 2(4), 14-27.

[23] Galvan, L. (2013). Writing literature reviews: A guide for students of the social and behavioral sciences. Glendale, CA: Pyrczak.

[24] Gollin-Kies, S. (2014). Methods reported in ESP research articles: A comparative survey of two leading journals, English for Specific Purposes, 36, 27-34.

[25] Grabe, W. \& Stoller, L. (2002). Teaching and researching reading. Harlow: Longman.

[26] Habbash, M. \& Albakrawi, H. (2014). Needs Analysis of Engineering Students' English Needs at the University of Tabuk, Journal of Education and Practice, 5(38) 68-75.

[27] Hutchinson, T. \& Waters, A. (1987). English for Specific Purposes: a learning-centered approach, Cambridge: Cambridge University Press.

[28] Javid, C., A-Asmari, A. \& Faooq, U. (2012). Saudi Undergraduates' Motivational Orientations towards English Language Learning along Gender and University. Major Lines: A Comparative Study, European Journal of Social Sciences, 27(2), 283300.

[29] Javid, C. \& Umer, M. (2013). Investigating English Language Needs: Medical Undergraduates Perspective in a Saudi Context, Pakistan Journal of Social Sciences (PJSS). 33(2), 363-377.

[30] Jenkins, J. (2007). English as a Lingua Franca: Attitude and Identity. Oxford: Oxford University Press.

[31] Jordan, R (2003). English for Academic Purposes: A guide and resource book for teachers. Cambridge: Cambridge University Press.

[32] Kennedy, C. (1985). 'Teacher as researcher and evaluator: One suggested solution to some recurrent problems in ELT and ESP'. Presented at the National ESP Conference, Vitoria, Brazil.

[33] Kumar, R. (2010). Research Methodology: A step-by-step guide for beginners, 3 ed. London: Sage.

[34] Liton, A. (2015). ESP Learners' Needs Related Learning for the Workplace: A Pragmatic Study for Business School, International Journal of Instruction, 8(2), 1-14.

[35] Long, H. (2005). Methodological issues in learner needs analysis. In M. H. Long, (Ed.), Second language needs analysis (pp. 19-76). Cambridge: Cambridge University Press.

[36] Mackey, A. \& Grass, S. (2016). Second Language Research: Methodology and Design, $2^{\text {nd }}$ ed., New York: Rutledge.

[37] Mahib ur Rahman, M. (2012). An Evaluation of English Writing Text at the Preparatory Year, Najran University, Saudi Arabia, Academic Research International, 2(2), 706-715.

[38] Mitchell, R. \& Myles, F. (2004). Second Language Learning Theories, $2^{\text {nd }}$ ed. , New York: Routledge.

[39] Mousawa, D. \& Elyas, T. (2015). Presentation as Employability Soft Skill to ESP Learners in the English Language Institute at King Abdulaziz University, Journal of Language Teaching and Research, 6(5), 1058-1062.

[40] Naser, A. (2015). Vocabulary Recognition Strategies: Theory and Practice within ESP Domains, English for Specific Purposes, World, 16(1), 1-19.

[41] Nickerson, C. (2005). English as a lingua franca in international business contexts, English for Specific Purposes, 24, 367-380.

[42] Nunan, D. (1999). Second Langue Teaching and Learning. Boston, Mass.: Heinle and Heinle.

[43] Paltridge, B. \& Starfield, S. (2012). The Handbook of English for Specific Purposes, Chichester: Wiley Blackwell.

[44] Pierce, B. (1995). Social Identity, Investment, and Language Learning, TESOL Quarterly, 29(1), 9-31.

[45] Pica, T. (1997). Second Language Teaching and Research Relationship: A review of North American View, Language Teaching Research, 1(1), 48-72.

[46] Rahman, M. \& Alhaisoni, E. (2013). Teaching English in Saudi Arabia: Prospects and challenges. Academic Research International, 4(1), 112-118.

[47] Richards, J. \& Rodgers, T. (2001). Approaches and Methods in Language Teaching. Cambridge: Cambridge University Press.

[48] Robinson, P. (1991). ESP today.UK: Prentice Hall International ltd.

[49] Strevens, P. (1988). ESP after twenty years: A re-appraisal. In M. Tickoo (Ed.), ESP: State of the Art (pp. 1-13). Singapore: SEAMEO Regional Centre.

[50] Teddlie, C., \& Tashakkori, A. (2009). The foundations of mixed methods research: Integrating quantitative and qualitative techniques in the social and behavioral Sciences. Thousand Oaks, CA: Sage.

[51] Tatweer. (n.d). King Abdullah Project for developing the Saudi education system. Retrieved from http://www.tatweer.edu.sa/content/aboutus on February 10, 2014.

[52] Younes, Z. (2016). THE Effectiveness of Using ESP Courses for PYP Saudi Female Learners of, Asian Journal of Educational Research, 4(4), 9-27.

Muhammad Al-Roomy received his PhD degree in education from Sussex University, Brighton, United Kingdom in 2013. He is currently an assistant professor at King Saud bin Abdulaziz University for health sciences at Riyadh, Saudi Arabia. He teaches both general and medical English for ESP students. His research interests include teaching reading skills, grammar, oral skills, students' beliefs and attitudes toward English and ESP research. 